\title{
DUKUNGAN SOSIAL KOMUNITAS KUSIR ANDONG
}

\author{
Harisal \\ Fakultas Psikologi \\ Universitas Ahmad Dahlan \\ harisal1700013090@webmail.uad.ac.id
}

\begin{abstract}
Abstrak
Komunitas andong merupakan sekelompok individu yang mampu mempertahankan transportasi tradisional dan rela mendapatkan penghasilan yang tidak seberapa dengan kebutuhan hidup kusir dan kudanya, Karena adanya dukungan sosial dari komunitas mereka yang masih bisa mempertahankan hidup. Mempuyai beberapa dukungan sosial, yaitu, dukungan emosi, penghargaan, instrumental, informasi, dan jaringan, tidak hanya itu Dukungan sosial yang diberikan oleh idividu mampu meningkatkan keyakinan individu mengenai kemampuannya dalam menyelesaikan masalah.
\end{abstract}

Kata kunci: dukungan sosial, komunitas kusir andong

\section{PENDAHULUAN}

Komunitas adalah sekelompok atau kumpulan orang yang saling berbagi lingkungan, perhatian, masalah, saling berbagi pengalaman, serta memiliki keterkaitan atau kegemaran yang sama terhadap suatu topik, dan dapat memperdalam pengetahuan serta keahliannya dengan saling berinteraksi secara terus menerus (wenger, 2002). Wellman dan Delanty (2003) menjelaskan bahwa komunitas adalah jaringan dari beberapa individu yang berbentuk kekeluargaan, saling mengikat dalam meningkatkan sosialisasi sesama jaringan, saling mendukung dan mensuport satu sama lain, memberikan informasi, adanya rasa memiliki persatuan yang erat dan menjadi identitas sosial. Menurut Hermawan (2008) komunitas adalah sekelompok atau kumpulan individu yang memiliki kepedulian satu sama lain lebih dari jumlah seharusnya, dimana sebuah komunitas terjadi relasi pribadi yang erat antara para anggota komunitas tersebut terhadap suatu ketertarikan hal yang sama.

Salah satu komunitas yang ada di Yogyakarta adalah komunitas andong. Andong merupakan kendaraan tradisional di Yogyakarta beroda empat yang ditarik kuda dan dikendalikan oleh pengemudi andong yang biasa disebut kusir (Dewi, 2012. Meningkatnya jumlah transportasi mesin yang lebih murah dapat 
berdampak pada rendahnya peminat jasa andong, hal tersebut juga berdampak pada rendahnya pengasilan, oleh karenanya dibutuhkan dukungan sosial dari sesama anggota komunitas untuk terus melestarikan transportasi andong di Yogyakarta. Berdasarkan latar belakang di atas, tujuan dari penulisan ini adalah ingin mengetahui dampak rendahnya dukungan sosial dan dampak tingginya dukungan sosial bagi anggota komunitas kusir andong.

\section{PEMBAHASAN}

Menurut Johnson dan Jhonson (1991) dukungan sosial merupakan keberadaan orang lain yang dapat diandalkan untuk memberi bantuan, semangat, penerimaan dan perhatian, sehingga bisa meningkatkan kesejahteraan hidup bagi individu yang bersangkutan. Dukungan sosial adalah sekumpulan dari proses sosial, emosional, kognitif, dan perilaku yang terjadi dalam hubungan pribadi, dimana individu yang merasa mendapat bantuan dalam melakukan penyesuaian atas masalah masalah yang di hadapi (Dalton, Elias, \& Wardersman, 2001). Dimatteo (2004) mendefinisikan dukungan sosial sebagai dukungan atau bantuan yang yang berasal dari orang lain seperti teman, tentang, teman kerja dan orangorang lainnya. Santrok (2006) mengemukakan bahwa dukungan sosial adalah sebuah informasi atau tanggapan dari pihak lain yang disayangi dan dicintai yang menghargai dan menghormati dan mencakup suatu hubungan komunikasi dan situasi yang saling bergantung. Dukungan soial mengacu kenyamanan, kepedulian, penghargaan, atau bantuan yang diterima oleh seseorang dari orang lain atau kelompok (Sarafino, 2008).

Menurut Sarafino (2002) ada lima jenis dukungan sosial, yaitu: dukungan emosi, dukungan penghargaan, dukungan instrumental, dukungan informasi, dan dukungan jaringan.

1) Dukungan Emosi

Dukungan dalam bentuk ini meliputi ungkapan rasa empati, kepedulian dan perhatian terhadap individu. Biasanya, dukungan bentuk ini diperoleh dari pasangan atau keluarga, seperti memberikan pengertian terhadap masalah yang sedang dihadapi atau mendengarkan keluhannya. Adanya dukungan ini 
akan lebih memberikan rasa nyaman, kepastian, perasaan memiliki dan dicintai kepada individu.

2) Dukungan Penghargaan.

Dukungan ini terjadi melalui ungkapan positif atau peng-hargaan yang positif pada individu, dorongan untuk maju atau persetujuan akan gagasan atau perasaan individu dan perbandingan yang positif individudengan orang lain (Sarafino,2002). Biasanya dukungan ini akan diberikan oleh atasan dan rekan kerja. Duku-ngan jenis ini, akan membangun suatu perasaan berharga, kompeten dan bernilai

3) Dukungan Instrumental atau Konkrit.

Dukungan jenis ini akan meliputi bantuan secara langsung. Biasanya dukungan ini, lebih sering diberikan oleh teman atau rekan kerja, seperti bantuan untuk menyelesaikan tugas yang menumpuk atau meminjamkan uang atau lain-lain yang dibutuhkan individu. Menurut Jacobson (Moertono, 1997) adanya dukungan ini, menggambarkan tersedianya barang-barang (materi) atau adanya pelayanan dari orang lain yang dapat membantu individu dalam menyelesaikan masalahnya. Selanjutnya hal tersebut akan memudahkan individu untuk dapat meme-nuhi tanggung jawab dalam menjalankan perannya sehari-hari.

4) Dukungan informasi.

Dukungan jenis ini meliputi pemberian nasehat, saran atau umpan balik kepada individu. Dukungan ini, biasanya diperoleh dari sahabat, rekan kerja, atasan atau seorang profesional seperti dokter atau psikolog. Adanya dukungan informasi, seperti nasehat atau saran yang diberikan oleh orang lain yang pernah mengalami keadaan yang serupa akan membantu individu memahami segala situasi dan mencari alternatif pemecahan masalah yang ada, atau tindakan yang akan diambil (Thoits dalam Moertono, 1997).

5) Dukungan Jaringan Sosial.

Dukungan jaringan dengan memberikan perasaan bahwa individu adalah anggota dari kelompok atau kesatuan tertentu dan memiliki minat yang sama. Rasa kebersamaan yang kuat dengan anggota kelompok merupakan dukungan bagi individu yang bersangkutan. Menurut Cohen, Wills \& Cutrona (dalam 
Moertono,1997) adanya dukungan jaringan sosial akan membantu individu untuk mengurangi stres yang dialami dengan cara memenuhi kebutuhan akan persahabatan dan kontak sosial dengan orang lain. Hal tersebut juga akan membantu individu untuk mengalihkan perhatiannya dari kekhawatiran yang ada, terhadap masalah yang dihadapinya atau dengan meningkatkan suasana hati yang positif.

Dukungan sosial sangatlah penting dimiliki oleh setiap individu. Dukungan sosial yang diberikan dapat secara verbal maupun nonverbal, seperti pujian maupun hadiah. Dukungan sosial dalam bentuk pendampingan secara khusus juga sangat dibutuhkan individu dalam menghadapi masalahnya (Tentama, 2012: 2012; 2009).

Manfaat dukungan sosial menurut Johnson dan Johnson (2000) adalah mampu meningkatkan 1) produktivitas, melalui peningkatan motivasi, kualitas penalaran, kepuasan kerja dan mengurangi dampak stres kerja. 2) kesejahteraan psikologi dan kemampuan penyesuaian diri melalui perasaan memiliki, kejelasan identitas diri, harga diri, pencegahan neurotisme dan psikopatologi, pengurangan distres, dan penyediaan sumber yang dibutuhkan. 3) kesehatan fisik dan 4) manajemen stres yang produktif melalui perhatian, informasi, dan umpan balik yang diperlukan untuk melakukan penanganan terhadap stres. Sementara itu menurut Tentama (2024) dampak positif bagi individu yang memiliki dukungan sosial adalah individu memiliki kepercayaan diri yang baik, merasa diterima, merasa disayangi, merasa diperhatikan, dan merasa diakui bila diberi. Lieberman (1992) mengemukakan bahwa dukungan sosial dapat menurunkan kecendrungan munculnya kejadian yang dapat mengakibatkan stres, apabila kejadian tersebut muncul, interaksi orang lain memodifikasi atau mengubah persepsi individu pada kejadian tersebut dan oleh jarena itu akan mengurangi potensi munculnya stres. Dukungan sosial yang diberikan oleh idividu mampu meningkatkan keyakinan individu mengenai kemampuannya dalam menyelesaikan tugas dan memecahkan masalah (Hurlock, 1980). 


\section{KESIMPULAN}

Komunitas adalah sekelompok atau kumpulan individu yang memiliki kepedulian satu sama lain, sedangkan andong merupakan kendaraan tradisional di Yogyakarta beroda empat yang ditarik kuda dan dikendalikan oleh pengemudi andong yang biasa disebut kusir, hal ini berdampak pada rendahnya pengasilan, oleh karenanya dibutuhkan dukungan sosial dari sesama anggota komunitas untuk terus melestarikan transportasi andong di Yogyakarta. Dukungan sosial mengacu pada kenyamanan, kepedulian, penghargaan, atau bantuan yang diterima oleh seseorang dari orang lain atau kelompok. Terdapat ada lima jenis dukungan sosial, yaitu: dukungan emosi, penghargaan, instrumental, informasi, dan jaringan. Manfaat dukungan sosial yang mampu meningkatkan 1) produktivitas, melalui peningkatan motivasi kepuasan kerja dan mengurangi dampak stres kerja. 2) kesejahteraan psikologi dan kemampuan penyesuaian diri melalui perasaan memiliki, kejelasan identitas diri, harga diri, pencegahan neurotisme dan psikopatologi, pengurangan distres, dan penyediaan sumber yang dibutuhkan. 3) kesehatan fisik dan 4) manajemen stres yang produktif melalui perhatian, informasi, dan umpan balik yang diperlukan untuk melakukan penanganan terhadap stres. Dukungan sosial dapat menurunkan kecendrungan munculnya kejadian yang dapat mengakibatkan stres, selain itu dukungan sosial yang diberikan oleh idividu mampu meningkatkan keyakinan individu mengenai kemampuannya dalam menyelesaikan tugas dan memecahkan masalah. 


\section{DAFTAR PUSTAKA}

Dalton, J. H., Elias, M. J., \& Wardersman, A. ( 2001). Community psychology, lingking individuals and communities. Balmont: Wadworth/ Thomson Learning.

Dewi, R. E. (2012). Menyusut, jumlah andong tinggal 358 unit. http://jogja.tribunnews.com/2012/09/05/menyusut-jumlah-andong-tinggal358-unit.

DiMatteo, M. R. (2004). Social support and patient adherence to medical treatment: a meta-analysis. Health Psychology, 23(2), 207-218.

Hermawan. K (2008). Arti komunitas. Jakarta: Gramedia Pustaka Utama.

Hurlock. E. B. 1980. Psikologi perkembangan: Suatu pendekatan sepanjang. rentang kehidupan. Jakarta: Airlangga.

Johnson, D. W. \& Jhonson, F. P. (1991). Joining together: Group theory and group skills. London: Prentice Hall International.

Johnson, D. W., \& Johnson, F. P. (2000). Joining together: Group theory and group skill. New Jersey: Prentise Hall.

Lieberman, M. A (1992). The effects of social support on responses to stres. London: Collier Macmilian Publisher.

Santrock, J. W. (2006). Adolescence. Jakarta: Penerbit Erlangga

Sarafino, E. P. (2002). Health psychology biopsychosocial interactions. United State: John Wiley \& Sons, Inc.

Sarafino, E. P. (2008). Health psychology: Biopsychosocial interactions 6th ed. United. States: john willey \& sons,Inc.

Tentama, F. (2014). Peran dukungan sosial pada gangguan stres pascatrauma. Republika, 95.

Tentama, F. (2009).Peran orang tua dan guru dalam menangani perilaku hiperaktifitas pada anak ADHD di SLB Negeri 3 Yogyakarta. Jurnal Penelitian dan Kajian Ilmiah Kesehatan Masyarakat, 3(1), 51-57.

Tentama, F. (2012). Peraan guru tentukan pendidikan anak hiperaktif. Republika, 74.

Tentama, F. (2012). Peran orang tua mendidik anak ADHD. Republika, 116. 
Wellman, B., \& Gerard, D. (2003). 2012. Pengertian komunitas sosial. http://frontlinerinc.com/2012/02/pengaruhkomunitas-sosial-terhadapkeputusan-pembelian-dan-sikapterhadap-merek-part-1/

Wenger, E., McDermott, R. A., \& Snyder, W. (2002). Cultivating communities of practice: A guide to managing knowledge. Boston: Harvard Business Press. 